\title{
Effects of Water Temperature Change on the Hematological Responses and Plasma Cortisol Levels in Growing of Red Spotted Grouper, Epinephelus akaara
}

\author{
Hyun Chul Cho ${ }^{1}$, Ji Eun Kim ${ }^{1}$, Hyung Bae Kim ${ }^{2}$ and ${ }^{\dagger}$ Hea Ja Baek ${ }^{1}$ \\ ${ }^{l}$ Dept. of Marine Biology, Pukyong National University, Busan 608-737, Korea \\ ${ }^{2}$ Dept. of Marine Bio-Resources, Gangwon Provincial University, Gangnung 210-804, Korea
}

\begin{abstract}
This study was conducted to determine the stress response [ethological (operculum movement number $(\mathrm{OMN})$ ), hematological (hematocrit and hemoglobin), biochemical (glucose, cortisol and glutamic oxaloacetic transaminase (GOT))] in red spotted grouper, Epinephelus akaara during exposure of different water temperature in winter season. This species (Total length, $18.56 \pm 0.34 \mathrm{~cm}$ ) previously maintained in water temperature of $15^{\circ} \mathrm{C}$ were transferred to 15,20 and $25^{\circ} \mathrm{C}$. During experimental period (7 days), OMN, hematocrit $(\mathrm{Ht})$, glucose and GOT values were significantly high in $15^{\circ} \mathrm{C}$ when compared to 20 and $25^{\circ} \mathrm{C}$. Hemoglobin value was also increased at $15^{\circ} \mathrm{C}$, but no significant differences. There was no differences in cortisol levels among the temperature groups. No fish mortality was observed during the experimental period. From these results, $15^{\circ} \mathrm{C}$ is likely more stressful to red spotted grouper than $20^{\circ} \mathrm{C}$ and $25^{\circ} \mathrm{C}$. These observations confirm that red spotted grouper adapts better to temperatures between 20 and $25^{\circ} \mathrm{C}$ during the winter season.
\end{abstract}

Key words : red spotted grouper, Epinephelus akaara, hematological responses, cortisol, glucose

\section{INTRODUCTION}

Temperature is one of common variables in the aquatic environment that directly affect survival of marine organisms. The ability to tolerate various temperature ranges differs with species (Kindle \& Whitmore, 1986). Under culture conditions, fluctuations in water temperature affect the enzyme reaction, growth efficiency, reproduction and immune ability in fish and sudden fluctuation in water temperature that exceed the threshold values often cause deaths of fish (Chatterjee et al., 2004; Cheng et al., 2013). Temperature also changes the physiological functions associated with the stress response of fish. The physiological stress response in fish firstly includes the release of stress hormones such as cortisol. An increase in plasma cortisol levels of fish is generally followed by an elevation in plasma glucose levels. Biochemical parameters, such as cortisol and glucose levels in plasma can be used as general stress indicators in fish (Santos \& Pacheco, 1996). In addition, hematological parameters included hematocrit and hemoglobin are good indicator to assess fish health management in various conditions such as exposure of stress (Chen et al., 2004).

The red spotted grouper, Epinephelus akaara is a serranid

\footnotetext{
Manuscript received 3 January 2015, Received in revised form 15 January 2015, Accepted 10 February 2015

${ }^{\dagger}$ Corresponding Author : Hea Ja Baek, Dept. of Marine Biology, Pukyong National University, Busan 608-737, Korea, Tel. : +82-51-629-5924, Fax : +82-51-629-5931, E-mail : hjbaek@pknu.ac.kr

This is an Open Access article distributed under the terms of the Creative Commons Attribution Non-Commercial License (http:// creativecommons.org/licenses/by-nc/3.0) which permits unrestricted non-commercial use, distribution, and reproduction in any medium, provided the original work is properly cited.
} 
fish distributed mainly in southern Japan, Korea, China and economically important species in aquaculture industry. Broodstock management and larval rearing techniques of red spotted grouper have been studied for aquaculture of this species.

Changes in the hematological and biochemical responses to water temperature shock have been studied in goldfish, rainbow trout, tilapia, atlantic cod, silver catfish and olive flounder (Basu et al., 2001; Lermen et al., 2004; Yang \& Yeo, 2004; Gollock et al., 2006; Hur \& Habibi, 2007; Jeong et al., 2012). However, none of the studies explored the physiological stress responses to temperature shock in red spotted grouper.

Therefore, we investigated the hematological and biochemical responses in red spotted grouper during and after exposure to water temperature shock. This study may help in promoting suitable grouper culture management in aquaculture.

\section{MATERIALS AND MATHODS}

\section{Experiment design}

Red spotted grouper ranging in weight from 47.6 to $90.8 \mathrm{~g}$ were obtained from a private farm (Muangun, Jeollanamdo, Korea) in winter season. The fish were shipped to the laboratory and acclimated in glass aquaria $(80 \times 60 \times$ $40 \mathrm{~cm}$ ) with running seawater of $34 \pm 0.5 \%$ at water temperature of $15.0 \pm 1.0^{\circ} \mathrm{C}$ for 3 weeks. The water temperature of the rearing facility was increased from $15^{\circ} \mathrm{C}$ to $25^{\circ} \mathrm{C}$ stepwise at rate of $1^{\circ} \mathrm{C} \mathrm{h}^{-1}$ and kept at 15,20 and $25^{\circ} \mathrm{C}$ for experimental periods ( 7 days). During the acclimation period, the fish were fed artificial feed twice a day, but were not feed $24 \mathrm{~h}$ prior to the experiment. During the experimental period, the salinity, dissolved oxygen, and $\mathrm{pH}$ were maintained at $34 \pm 0.5 \%$, $6.5 \pm 1.0 \mathrm{mg} \mathrm{l}^{-1}$, and $7.8 \pm 0.3$, respectively.

\section{Fish sampling}

For analysis of the hematological and biochemical responses, fish ( $n=3$ fish/group) were randomly collected from each exposure group ( 15 as control, 20 and $25^{\circ} \mathrm{C}$ ) at 2 and 7 days and anesthetized in 0.1\% 2-phenoxyethanol in seawater. The blood was immediately collected from caudal artery with a heparinized $2 \mathrm{~mL}$ syringe.

\section{Hematological analyses}

Hematological indices were determined such as hematocrit (Ht) values and hemoglobin $(\mathrm{Hb})$ levels. Ht values were determined after blood sampling using glass capillary tubes and centrifuged for $5 \mathrm{~min}$ at $12,000 \mathrm{rpm}$ in a microhematocrit centrifuge (HAWKSLEY AND SONS Ltd., England). Hematocrit readings were performed with microhematocrit reader (HAWKSLEY AND SONS, England). $\mathrm{Hb}$ levels were measured by cyanomethemoglobin method according to Lee et al. (1998).

\section{Biochemical analyses}

Collected blood was separated by centrifugation (15 min at $13,000 \mathrm{rpm}$ ) at $4^{\circ} \mathrm{C}$ and stored at $-80^{\circ} \mathrm{C}$ until analysis. Glutamic oxaloacetic transaminase (GOT), glucose levels in plasma were assessed using an automatic analyser (FUJI DRI-CHEM 4000i, Fujifilm Co., Japan). The automatic analyser was operated using select testing slides (multilayered slides, Fujifilm Co., Japan) by reading the bar codes via lasers.

For measurement of cortisol level in plasma, steroids from plasma were extracted twice in $2 \mathrm{~mL}$ diethyl ether, dried under nitrogen gas and resuspended in phosphate buffer $(\mathrm{pH}=7.5)$. Plasma cortisol level was measured by radioimmunoassay (RIA) according to the Kobayashi's method (Kobayashi \& Mikuni, 1987). Antiserum for cortisol was purchased from Cosmo-Bio Co. Ltd. (Tokyo, Japan). Non-radioactive steroid standards was purchased from Steraloids Inc. (Wilton, NH, USA). Radio-labeled steroids $\left(\left[{ }^{3} \mathrm{H}\right]\right.$-cortisol) was purchased from Amersham Lifesciences 
(Piscataway, NJ, USA).

\section{Statistical analysis}

All data were expressed as means with the standard error of the means (SEM). Data analyses were based on ANOVA or Duncan's multiple range test and significance ascribed to differences at the 0.05 level.

\section{RESULTS}

No fish mortality was observed during the experimental period. Results of hematological and immunological activities analysis of red spotted grouper exposed to water temperature are presented in Fig. 1, 2 and 3, respectively.

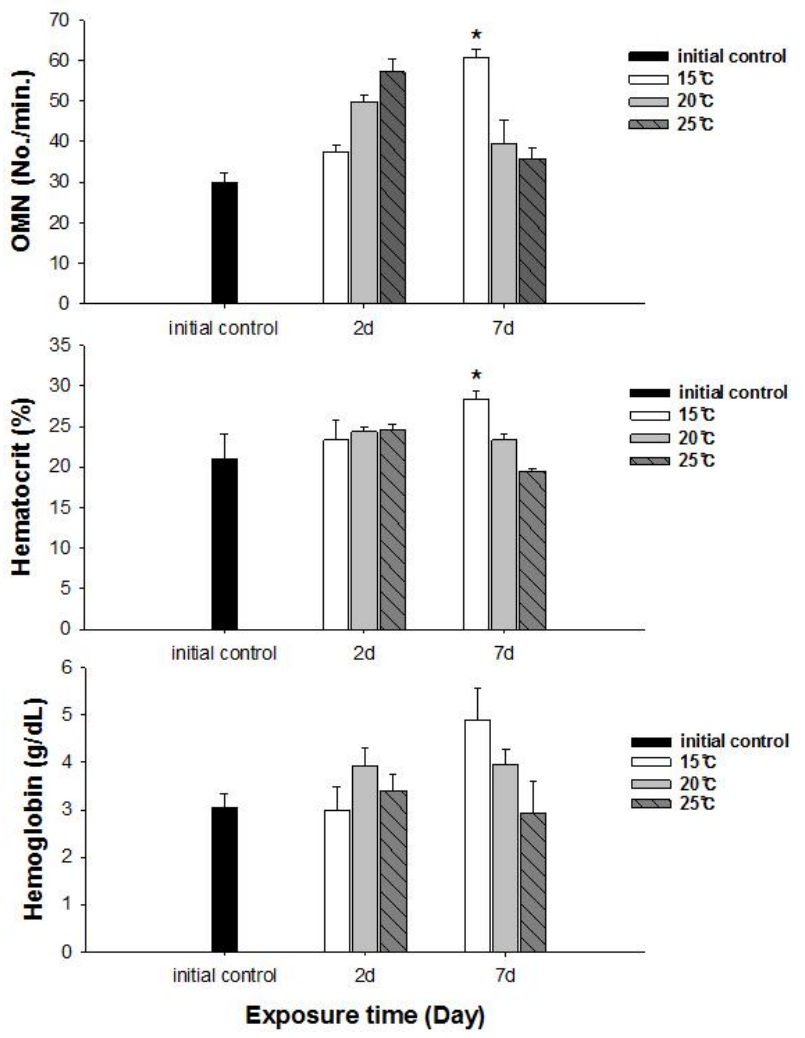

Fig. 1. Changes of operculum movement number (OMN), hematocrit and hemoglobin concentration of red spotted grouper exposed to water temperature. The values are mean $\pm \mathrm{SE}(\mathrm{n}=3) *$ Indicates significant differences between groups at equivalent times $(P<$ $0.05)$.
$\mathrm{OMN}$ of fish exposed to $15^{\circ} \mathrm{C}$ lowest among temperature treatment groups at 2 days after exposure (DAE) but showed significantly increase at 7 DAE $(P<0.05$; Fig. 1$)$. In hematological indices, both $\mathrm{Ht}$ and $\mathrm{Hb}$ had no differences among fish from temperature groups at 2 DAE. However, $\mathrm{Ht}$ and $\mathrm{Hb}$ values changed within each treatment groups at 7 DAE. Red spotted grouper exposed to $15^{\circ} \mathrm{C}$ had significantly higher $\mathrm{Ht}$ value at $7 \mathrm{DAE}(P<0.05$; Fig. 1$)$. In biochemical indices, plasma glucose levels within each experimental group were similar to the hematological responses. At 7 DAE, plasma glucose levels had apparent elevation at $15^{\circ} \mathrm{C}$. No differences in plasma cortisol levels were found within each treatment throughout the experiment period $(P<0.05$; Fig. 2$)$ Also, GOT level in plasma was significantly increased at water temperature of $15^{\circ} \mathrm{C}$ $(P<0.05$; Fig. 3). During the experimental period, the correlation between water temperatures with all parameters
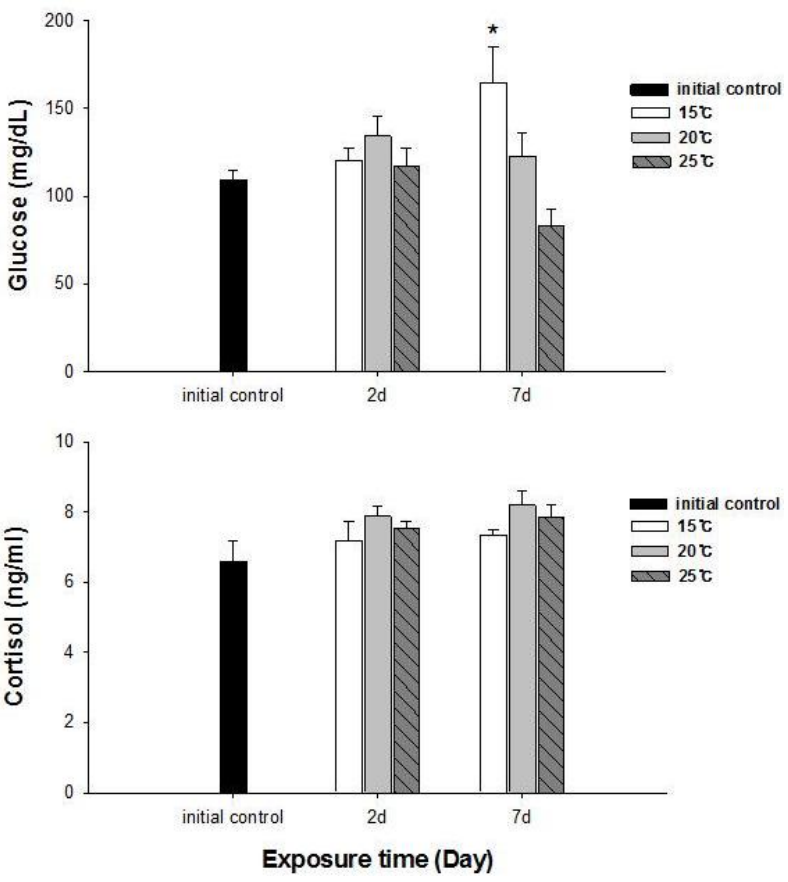

Fig. 2. Changes of plasma glucose and cortisol levels in red spotted grouper exposed to water temperature. The values are mean $\pm \mathrm{SE}(\mathrm{n}=3) *$ Indicates significant differences between groups at equivalent times $(P<0.05)$. 


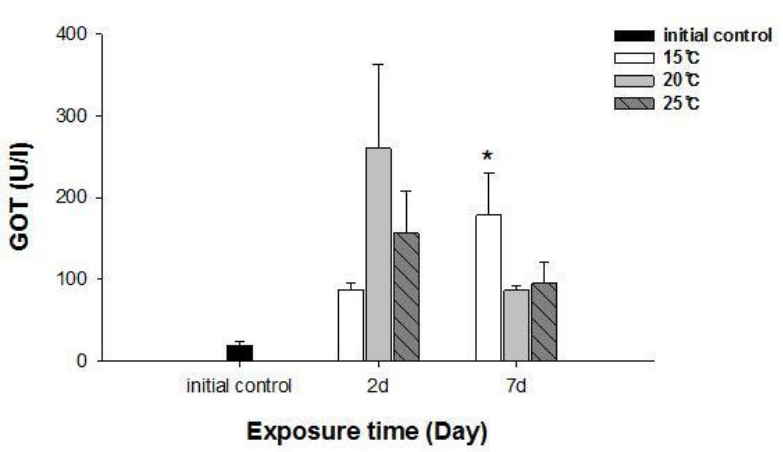

Fig. 3. Changes of GOT activities in red spotted grouper exposed to water temperature. The values are mean $\pm \mathrm{SE}(\mathrm{n}=3) *$ Indicates significant differences between groups at equivalent times $(P<0.05)$

tested in this experiment was statistically tested by analyzing the data obtained during the water temperature exposure. Only OMN, glucose, Ht and GOT levels showed significant correlation $(P<0.05)$ with water temperature of $15^{\circ} \mathrm{C}$ that these parameters confirmed positive correlation.

\section{DISCUSSIONS}

Most groupers are considered to be commercially important marine fish in southeastern Asia. In particular, the red spotted grouper (Epinephelus akaara) is a highly priced market values fish in this region (Rimmer, 2004; Lee et al., 2014). Groupers have been reared are warm water fish that spawn and grow best at 24 to $30^{\circ} \mathrm{C}$; most of them can tolerate a range of 15 to at least $35^{\circ} \mathrm{C}$ (Tucker, 1999). The present study was performed to evaluate the impact of different temperature range $\left(15^{\circ} \mathrm{C}, 20^{\circ} \mathrm{C}\right.$, and $25^{\circ} \mathrm{C}$ ) on the growing of red spotted grouper during the winter season. For the control group, temperature was kept at $15^{\circ} \mathrm{C}$ that is over-wintering temperature.

We determined the opercula activity, hematocrit, hemoglobin, glucose, cortisol, and GOT levels at the end of experiment. During the experiment period (7 days), OMN, hematocrit $(\mathrm{Ht})$, glucose and GOT values were significantly high in $15^{\circ} \mathrm{C}$ when compared to 20 and $25^{\circ} \mathrm{C}$. Hemoglobin value was also increased at $15^{\circ} \mathrm{C}$, but no significant differences.

Cortisol and glucose levels are general stress indicators in fish (Pacheco \& Santos, 2001). In this study, plasma glucose values were not correlated to the observed plasma cortisol response. There was no differences in cortisol levels among the temperature groups. Chen et al. (1995) reported that plasma cortisol concentrations increased in common carp only after acute exposure to $4^{\circ} \mathrm{C}$, but in the chronic experiment, they returned to levels similar to those of the control group. The results obtained with silver catfish (Rhamdia quelen) showed that plasma cortisol levels were unchanged in both the acute and chronic treatments (Lermen et al., 2004). High blood glucose levels at low temperatures is indicative of retarded metabolism, and is also an index of sub-lethal stress (Best et al., 2001). In our results, $15^{\circ} \mathrm{C}$ is likely more stressful to red spotted grouper than $20^{\circ} \mathrm{C}$ and $25^{\circ} \mathrm{C}$ during the winter. Moreover, glucose was a better index than the cortisol in this fish. In addition, a significantly higher value of GOT activity was recorded in $15^{\circ} \mathrm{C}$. This coincides with the increase in value of glucose which is related to a decrease in glycogen reserves in the liver (Click \& Engin, 2005). Under cold conditions, the silver catfish spared glucose, resulting in gluconeogenesis, whereas in the warm water, it likely consumes glucose (Lermen et al., 2004). Tandon \& Joshi (1974) reported that serum glucose level increased with the fall of temperature in Clarias batrachus. They observed the highest blood glucose level during the winter and lowest during the summer and correlated it with the lowering of temperature.

Hematological parameters such as $\mathrm{Ht}$ and $\mathrm{Hb}$ are used to assess the functional status of the oxygen carrying capacity of the blood stream (Shah \& Altindag, 2004) and assess the physiological status of fish under the stressed condition (Fernandez \& Mazon, 2003). Opercular beat rate also has been used to provide a measure of response to stress in 
fishes. Counting operculum movement is a way to calculate respiration rates. Increased opercular activity can lead to increased oxygen consumption (Dalla Valle et al., 2003). Gibson \& Mathis (2006) explained that opercular beat rate as an assay for thermal stress alone is limited due to the responsiveness in a variety of contexts. This behavior, however, appears to be another reliable response in predator recognition, and could be preparatory to offensive or defensive movements, or exploratory behavior (Rottmann et al., 1992). Our results showed increase in both $\mathrm{Ht}$ and $\mathrm{OMN}$ at $15^{\circ} \mathrm{C}$ temperature. These observations along with the results of glucose level in plasma confirm that red spotted grouper adapts better to temperatures between 20 and $25^{\circ} \mathrm{C}$ during the winter season.

\section{ACKNOWLEDGEMENTS}

This research (213004-04-2-SB620) was supported by Ministry of Agriculture, Food and Rural Affairs (MAFRA), Ministry of Oceans and Fisheries (MOF), Rural Development Administration (RDA) and Korea Forest Service (KFS).

\section{REFERENCES}

Basu N, Nakano T, Grau EG, Iwama GK (2001) The effects of cortisol on heat shock protein 70 levels in two fish species. Gen Comp Endocrinol 124:97-105.

Best JH, Eddy FB, Codd GH (2001) Effects of purified microcystin-LR and cell extracts of Microcystis strains PCC 7813 and function in brown trout (Salmo trutta) alevins. Fish Physiol Biochem 24:171-178.

Chatterjee N, Pal AK, Manush SM, Das T, Mukherjee SC (2004) Thermal tolerance and oxygen consumption of Labeo rohita and Cyprinus carpio early fingerings acclimated to three different temperatures. J Therm Biol 29:265-270.

Chen CY, Wooster GA, Bowser PR (2004) Comparative blood chemistry and histopathology of tilapia infected with Vibrio vulnificus or Streptococcus iniae or exposed to carbon tetrachloride, gentamicin of copper sulfate. Aquaculture 239:421-443.

Chen GR, Sun LT, Lee YH, Chang CF (1995) Characteristics of blood in common carp, Cyprinus carpio, exposed to low temperatures. J Appl Aquaculture 5:2131.

Cheng SY, Chen CS, Chen JC (2013) Salinity and temperature tolerance of brown-marbled grouper Epinephelus fuscoguttatus. Fish Physiol Biochem 39:277-286.

Click B, Engin K (2005) The effects of cadmium on levels of glucose in serum and glycogen reserves in the liver and muscle tissues of Cyprinus carpio (Linnaeus, 1758). Turkish J Vet Anim Sci 29:113-117.

Dalla Valle AZ, Rivas-Diaz R, Claireaux G (2003) Opercular differential pressure as a predictor of metabolic oxygen demand in the starry flounder. J Fish Biol 63:1578-588.

Fernandez MN, Mazon AF (2003) Environmental pollution and fish gill morphology. In: Val AL, Kappor BG (ed.), Fish Adaptations. Scientific Publishers, Inc., Enfield, NH, pp 203-231.

Gibson AK, Mathis A (2006) Opercular beat rate for rainbow darters Etheostoma caeruleum exposed to chemical stimuli from conspecific and heterospecific fishes. J Fish Biol 69:224-232.

Gollock MJ, Currie S, Petersen LH, Gamperl AK (2006) Cardiovascular and haematological responses of Atlantic cod (Gadus morhua) to acute temperature increase. J Exp Biol 209:2961-2970.

Hur JW, Habibi HR (2007) Physiological response and hematological characteristics of goldfish (Carassius auratus) to water temperature shock. Korean J Ichthyol 19(2):93-100.

Jeong JW, Kim YS, Kang JC (2012) Combined effects of temperature and arsenic on hematological parameters 
of tilapia Oreochromis niloticus. J Fish Pathol 25:3946.

Kindle KR, Whitmore DH (1986) Biochemical indicators of thermal stress in Tilapia aurea (Steindachner). J Fish Biol 29:243-255.

Kobayashi Y, Mikuni T (1987) A fundamental and clinical study of ferritin 'Eiken' radioimmunoassay kit. Radioisotpes 36(1):28-31.

Lee CH, Hur SW, Na OS, Baek HJ, Noh CH, Gan SH, Lee YD (2014) Induction of primary male in juvenile red spotted grouper Epinephelus akaara by immersion of $17 \alpha$-methyltestosterone. J Reprod Dev 18:127-131.

Lee GR, Foerster J, Lukens J, Paraskevas F, Greer JP, Rodgers GM, Wintrobe MM (1998) Wintrobe's Clinical Hematology, $10^{\text {th }}$ edition. Lippincott Williams \& Wilkins, New York, pp 1013.

Lermen CL, Lappe R, Crestani M, Vieira VP, Gioda CR, Schetinger MRC, Baldisserotto B, Moraes G, Morsch VM (2004) Effect of different temperature regimes on metabolic and blood parameters of silver catfish Rhamdia quelen. Aquaculture 239:497-507.

Pacheco M, Santos MA (2001) Biotransformation, endocrine, and genetic responses of Anguilla Anguilla L. to petroleum distillate products and environmentally contaminated waters. Ecotoxicol Environ Saf 49:64-75.

Rimmer MA (2004) Introduction. In: Rimmer MA, McBride S, William KC (Eds.), Advances in Grouper Aquaculture. ACIAR Monograph 110, Canberra, pp 1-5.

Rottmann RW, Francis-Floyd R, Durborrow R (1992) The role of stress in fish disease. Southern Regional Aquaculture Center Publication No. 474. College Station, TX: Texas A \& M University.

Santos MA, Pacheco M (1996) Anguilla anguilla L. Stress biomarkers recovery in clean water and secondary treated pulp mill effluent. Ecotoxicol Environ Saf 35:96-100.

Shah SL, Altindag A (2004) Hematological parameters of tench (Tinca tinca L.) after acute and chronic exposure to lethal and sublethal mercury treatment. Bull Environ Contam Toxicol 73:911-918.

Tandon RS, Joshi BD (1974) Effect of trypanosome infection on blood glucose levels of some fresh water teleosts. J Inland Fish Soc India 6:81-82.

Tucker JW Jr (1999) Species Profile Grouper Aquaculture, Southern Regional Aquaculture Center Publication 721 Fort Pierce, Florida.

Yang JH, Yeo IK (2004) Physiological studies on acute water-temperature stress of olive flounder (Paralichthys olivaceus). Korean J Ichthyol 16:19-26. 